\title{
The Efficiency of Entrepreneurship Indicators and Policy Implications in West Africa
}

\author{
Akinseye Olowu $^{1 *} \quad$ Edwin Ijeoma ${ }^{2}$ \\ 1.Department of Entrepreneurship, Joseph Ayo Babalola University, Nigeria \\ 2.School of Government \& Public Administration, University of Fort Hare, South Africa
}

\begin{abstract}
This study investigated the efficiency of entrepreneurship at macro level in anglophone and francophone West African, using selected indicators across countries. The study made use of data envelopment analysis (DEA) approach to evaluate the performance. From the efficiency analysis on the Anglophone countries, there was an improvement in scale efficiency which implies that the countries within embraced technology and as well improved on their managerial allocative efficiency, and therefore optimizing their DMUs (countries) economies of scale. All the DMUs were constant under pure technical efficiency change (PECH) and scale efficiency change (SECH) except in Sierra Leone. While the efficiency analysis on the Francophone countries revealed a sharp decrease on average productivity but Mali, Benin and Burkina Faso experienced increase in productivity except in Ivory Coast where the productivity and technical efficiency was regressed. However, the general inefficiency/short-fall in all the countries examined was from their technical inefficiency in terms of managerial skills deficit required to optimally increase the return on outputs from the given set of inputs. Cumulatively, the findings revealed that PECH is less than SECH across the West African countries. It was however recommended that public policies should be more focused on engendering technical efficiencies of entrepreneurship pursuit in the Region.
\end{abstract}

Keywords: Entrepreneurship, Efficiency, Anglophone, Francophone, West Africa

DOI: $10.7176 / \mathrm{PPAR} / 9-8-02$

Publication date: August $31^{\text {st }} 2019$

\section{Introduction}

This study reports on an application of data envelopment analysis (DEA) to assess the performance of entrepreneurship indicators in selected anglophone and francophone countries of West Africa. The performance assessment aims at determining efficiency which in a broader sense refers to policy implications that allow countries to better utilize its resources towards promoting entrepreneurship. The need to ascertain the performance of entrepreneurship has spawned a remarkable re-engineering of policies to achieve its numerous advantages in the economy. According to Alan and Stuart (1999), government institutions such as the central banks all over the world stimulate market conditions through policies. However, the amount of entrepreneurial outcomes generated from a given amount of economic inputs depends primarily on the rules of the game, or policies, under which entrepreneurs operate. Recently, ECOWAS adopted a monitoring and evaluation mechanism for monitoring and executing Vision 2020 agenda, which is focus on poverty alleviation. This strategy is based on the consolidation of achievements, as well as the development and harmonization of sectoral policies. However, economic changes due to the dynamics of each individual country such as globalization, technological changes, politics and colonial antecedent are reasons why their macroeconomic policy stance and objectives differ. For instance, Anglophone countries in West Africa are known to operate independent macroeconomic regulatory institutions i.e. central banks in respective countries. The existence of the market could either have positive or adverse effects on entrepreneurship performances, when compared with Anglophone countries. Empirical studies on stock markets in West Africa have found that: it has an unidirectional casuality from finance to growth (Enisan \& Olufisayo (2009); that it has a positive significant relationship with domestic private investment; but has a negative and nonsignificant impact on foreign private investment (Ezeoha, Ogamba \& Onyiuke, 2009); that long-run relationship exist between stock market and development and growth (N'zue, 2006); that the overall stock market development has a significant impact on economic growth (Adjasi \& Biekpe, 2006); and that there were significant positive relationship between stock market and overall financial development (Beck \& Levine, 2004). Indeed, the emergence of stock markets in West Africa calls for an assessment to inform policy makers on how to promote entrepreneurship through macroeconomic policies.

However, the macro environment, often used interchangeably with external environment encompasses variables that are not within the control of the entrepreneur. Entrepreneurship scholars have identified several of these external variables. Principal among the factors identified are the influences of regulations and polices (Baumol, 1990). These factors are of paramount importance to entrepreneurship because the assessment of the efficiency of policies helps the entrepreneur to identify conditions that may impede the progress of business and therefore, plan ahead to forestall such occurrence.This is necessary because in the evolution of public policy and governance, entrepreneurship is increasingly recognised as a crucial element in fostering economic development 
and growth, especially at the regional level. According to Huggins, Morgan and Williams (2015), regional entrepreneurship differentials emerged due to the spatial and place-based nature of three underlying factors: first, the nature of markets; second, the nature of innovation systems; and third, the nature of place-based cultures, communities and the institutions they establish. However, ECOWAS's Vision 2020 strategy aims to develop the region by harmonising sectoral policies across countries.

Coming to terms with the context of entrepreneurship indicators, the definitions of entrepreneurship are not exactly the same because it has been viewed from different perspectives. Taking a cue from an institutional attempt, the UNDP (2010) defined entrepreneurship as the process of using certain initiatives to transform a business concept into a new venture or to grow and diversify an existing venture or enterprise with high growth potential. Entrepreneurship is however often linked to economic growth. Likewise, Schumpeter, (1934) recognized the role of entrepreneurship in economic development However, entrepreneurship is a global phenomenon that is central to economies across the world and has gained rapid attention of policy makers because of its abilities to create wealth, generate income, output and employment (OECD, 2011). The recognition of entrepreneurship as a driver of economic growth has led policy analyst, researchers and economic theoreticians to improve on the measurement of entrepreneurship at country level. In this context, the study derived a measure of entrepreneurship across countries from previous studies by the Global Entrepreneurship Monitor (GEM), measures and drivers of knowledge economy, reports of the technology and innovation foundation, Bergmann et al., (2013): Murdock (2009), Saisana and Munda (2008), Atkinson \& Correa (2007), Allen (2001). However, we adopt the selected entrepreneurship indicators at macro level based on the previous studies as: economic growth, revenue from export, domestic private investment and equity portfolio/stocks which explains the entrepreneurship activities in countries.

\subsection{Problem statement}

Poor public policy undermines entrepreneurial behaviour and reduces public welfare (McCaffrey, 2015). While entrepreneurship is a central aspect of economic development and public policy concern in most countries, scholarly research about their entrepreneurial activities is comparatively scarce. Nevertheless, entrepreneurship and public policy touches on a variety of underlying issues that require addressing before policy formulations can be suggested in countries. An overlook of this fact may lead to policy failure, or unforeseen effects of public policies (Parker 2007). For instance, the relationship between the composition of government spending and entrepreneurship activity has been woefully under-researched (Islam, 2015). Entrepreneurship activities have been found all over the world to be capable of making positive impacts on the economy of a nation and the quality of life of the people.Yet, they are often hampered by the conditions in their business environment in most developing countries (Ncube, 2015). Many countries face the problem of inefficient utilization of various inputs or resources. According to Leibenstein (1987) the most significant attribute of entrepreneurship is gap filling. Entrepreneurship performance measurement is about checking for the inefficiencies in the utilization of various resources through unique ways. It is the duty of researchers and policy analyst to provide knowledge on the gap or deficiencies that exist in entrepreneurship activities. However, the deficiencies in production function arise because all the inputs in the production function cannot be put to adequate use. For instance some input are imprecise and their output is indeterminate. However, entrepreneurship is involved in the process of organizing all the inputs to achieve efficiency in an economy. Thus, entrepreneurship is a function of input completing and gap filling.

\section{Literature review}

The study adopts the financial capital/liquidity theory of Keynes (1936) which explains how liquidity scarcity is one relevant impediment to entrepreneurship activities and how entrepreneurships play an important role in the economy. In this sense, Keynes $(1930,1936)$ and Schumpeter (1934) approaches can be used as complementary to explain the liquidity situation and to provide adequate measure to eliminate it and reduce its negative effects in an economy. The theory implies that there must be enough funds to satisfy the investment necessities and this involve the functions of central banks to act as lenders of last resorts, so that monetary policies can accommodate such necessities while fiscal policies favours the disposable income status of citizens, corporations and entrepreneurs alike, in order to avoid financial problems. The theory is premised on the entrepreneurs' belief that financial capital is an economic resource measured in terms of money and used for productive purposes within the economy that their activities are based. Studies show that access to finance makes the establishment of new firms possible (Evans \& Jovanovic, 1989; Holtz-Eakin et al., 1994 and Blanchflower et al., 2001). This theory implies that the availability of financial capital made available by policies empowers people to acquire resources and to exploit entrepreneurial opportunities effectively (Clausen, 2006). It further explains that having access to capital at the beginning of an enterprise is a condition for predicting whether a new enterprise will grow but not necessarily important for the founding of a new venture (Hurst \& Lusardi, 2004). The importance of this theory is that the availability of finance promotes entrepreneurship activities in countries. Alege (2009) and Orisadare (2012), in their empirical study conclude that appropriate and suitable macroeconomic policies would be required for sustainable growth. However, despite the key place the policies ocupy in economic theory, empirical evidence is 
minimal on their effects on entrepreneurship in West Africa.

\section{Research methodology}

As a follow up to the objectives of the study, we consider efficiency as a measure of performance. However, various perspectives can be used and several internal and external factors can affect their outcomes while using the data envelopment analysis (DEA). Simon (1997) explains efficiency as fitness or power to accomplish or success in accomplishing the purpose intended. Later, efficiency acquired a second meaning of the ratio of inputs to outputs, between effort and results, expenditure and income and cost and the resulting pleasure (Ejiofor 1987).

\subsection{Efficiency methodology}

The limitations encountered by ration and regression methods brought about more advanced methods for measuring efficiency (Paradi \& Zhu, 2013). Not less than five major methods ranging from the non-parametric to a parametric approach have been used in literatures to measure efficiency (Banker et al., 1989; Bauer, 1990; Seiford and Thrall, 1990; Aly and Seiford, 1993; Greene, 1993; Grosskopf, 1993; Lovell, 1993; Charnes et al., 1994). Methods such as data envelopment analysis (DEA), free disposal Hull (FDH), stochastic frontier approach (SFA), distribution-free approach (DFA) and the thick frontier approach (TFA) However, these methods differ in specifications and assumptions (Thanassoullis et al., 1996). However, Bauer et al., (1998) exhaustively estimated the available methods and found the non parametric DEA to be consistent with other parametric methods in terms of efficiency distribution, and ranking order. As a corollary, Banker and Natarajan (2008) and Banker (1993) affirms that the DEA estimators have adequate statistical qualities to measure the effects of variables on performance. The efficiency of the entrepreneurship indicators is measured in selected Anglophone and Francophone countries in West Africa using DEA. It is generally understood that efficiency is influenced by an extensive range of factors, and the observed findings depend upon both the methodological approach utilized and the geographical area investigated. However, this differs across countries. These approaches differ in the assumptions imposed on the specifications of the inefficiencies and random error (Berger \& Humphrey, 1997; Thanassoullis, et al., 1996). The DEA approach developed by Charnes, Cooper and Rhodes (1978) is intended as a method for performance evaluation and benchmarking against best-practice. The DEA model is able to include multiple inputs and outputs, and because it has the potential to provide information to policy makers to improve the productive efficiency in countries.

\subsection{Model specification}

From literature on efficiency measurement, efficiency in this study was estimated using CCR (Charnes, Cooper \& Rhodes, 1978) and BCC (Baker, Charnes \& Cooper, 1984) models. These models incorporate the variable return to scale (VRS), the constant returns to scale (CRS) and scale efficiency in order to capture efficiency scores.

The CCR model is expressed as:

Virtual input $=\boldsymbol{v}_{1} \boldsymbol{x}_{1}+\cdots+\boldsymbol{v}_{\boldsymbol{i}} \boldsymbol{x}_{\boldsymbol{i}}=\sum_{i=1}^{m} \boldsymbol{v}_{\boldsymbol{i}} \boldsymbol{x}_{\boldsymbol{i}}$

while the Virtual output $=\quad \boldsymbol{u}_{\mathbf{1}} \boldsymbol{y}_{\mathbf{1}}+\cdots+\boldsymbol{u}_{\boldsymbol{r}} \boldsymbol{y}_{\boldsymbol{r}}=\sum_{r=1}^{s} \boldsymbol{u}_{\boldsymbol{r}} \boldsymbol{y}_{\boldsymbol{r}} \quad$ in order to specify the model to

measure entrepreneurship indicator efficiency, we have ten (n) DMUs using (m) input to produce (s) outputs. The technical efficiency (TE) is represented using the input orientation CCR model to give estimates of efficiency under the return to scale presented as:

$$
T E=\sum_{i=1}^{\varepsilon}\left(U_{r} Y_{r o}\right) \div \sum_{i=1}^{m}\left(V_{1} Y_{i o}\right)
$$

Efficiency

$$
=\frac{\text { Virtual output }=}{\text { Virtual input }} \frac{\sum_{r=1}^{s} u_{r} y_{r}}{\sum_{i=1}^{m} v_{i} x_{i}} \leq \mathbf{1}_{v_{r}, \boldsymbol{x} x_{i \geq 0,1=1, \ldots, m, j=1, \ldots \ldots, n, r=1, \ldots \ldots, s}}
$$

However, efficiency is attained by any DMU if and only if, none of its inputs or outputs can be improved without negatively affecting other inputs or outputs (Koopmans, 1951). The equation will be used for DEA by inculcating as a constraint. 


\subsection{Variable specification}

Not many studies have investigated the relationship between macroeconomic policies and entrepreneurship at cross country level. However, the few that exist regress a measure of entrepreneurship on policy instruments along with other control variables. The recognition of entrepreneurship as a driver of economic growth has led policy analyst, researchers and economic theoreticians to improve on the measurement of entrepreneurship at national level. For instance, at an international level, programs by the World Bank, Eurostat and private organisations such as GEM have developed an internationally comparable data (Ahmad and Hoffman, 2007). Therefore, the entrepreneurial activities in countries was adopted as our dependent variable measured by the entrepreneurship indicators as measured by the GEM minus innovation measures and given the peculiarities of availability of data. This is beacuse it is impossible to adopt the full indicators of entrepreneurship activities as measured previous studies, GEM and the knowledge economy indicators. However, we adopt specific entrepreneurship indicators for the study using OECD indicators in Ahmad and Hoffman (2007) along with some indicators of GEM and knowledge economy. The selected entrepreneurship indicators used in this study is explained as follows:

Revenue from export: this is the income realized from the exportation of creativity and innovativeness within the economy. According to Adesoji and Sotubo (2013) exportation is required by any economy to enhance revenue and usher in economic growth and development. Export is a catalyst necessary for the overall development of an economy (Abou-Strait, 2005). An increase of this variable in countries is an indication that the economy is entrepreneurial

Domestic private investment: there is a growing literature on the link between private investment and economic growth in developing countries due, largely, to the fact that developing countries are fond of formulating sound investment friendly policies to attract foreign investment studies by Khan and Reinhart (1990), Harigan and Mosely (1991), Greenway and Morrissey (1992), Serven and Salimano (992), Gunning (1994), Collier (1995), Akinyosoye, Akande, Akpokodje, and Mbanefoh (1998), Dehn (2000), Lemi and Asefa (2001), Mamatzakis (2001), Rashid (2005), Tawiri (2010). This variable is represented by the Gross fixed capital formation of the, private sector in countries.

Equity portfolio/stocks: due to the emerging trend of the region stock exchange markets in West Africa, we deem it fit as a variable for measuring entrepreneurship. More so capital markets contribute to economic growth in studies (Enisan and Olufisayo (2009), Ezeoha et al. (2009), N'zue (2006), Adjasi and Biekpe (2006), Beck and Levine (2004)). This is because liquidity is the means by which entrepreneurship activities are financed. More liquid markets channel more savings and also encourage investment in long-term projects that potentially have higher returns. Therefore, using lagged values of total value traded as a percentage of GDP, we expect liquidity to be positively correlated with the measure of stock market development.

Economic growth: this variable is measured by GDP per capital which is the total output of a country that takes the gross domestic product and divides it by the number of people in the country. We use real GDP per capita instead of real GDP to measure domestic income in our model. According to literature, high growth in real GDP per capita signifies increased entrepreneurship outcomes.

\subsection{Study population}

The population for the study comprises of five countries within both Anglophone and Francophone countries in West Africa. The ten countries namely; the Gambia, Ghana, Liberia, Nigeria, Sierra Leone, Code I'voire, Mali, Burkina Faso, Senegal and Benin. These countries were purposively selected into the divides based on the hierarchy of their GDP performance.

\subsection{Data sources}

Cross-country Panel data will be used to analyze the phenomenon in West Africa. The study derived annual data from ten selected countries from 2000 to 2014 period based on the secondary data from the World Bank Development Indicators.

\section{Presentation and analysis of results}

\subsection{The Efficiencies in Anglophone West African Countries}

During the period under review, the following observations were made on the: Total Factor Productivity Change (TFPCH); Technical Efficiency Change (EFFCH); Technological Change (TECHCH); Pure Technical Efficiency Change (PECH) and Scale Efficiency Change (SECH) of entrepreneurship indicators in Anglophone West African countries using a Data enveloping analysis (DEA).

2000-2001: on the average, there was high productivity retrogression by $20.4 \%$ in the period while technical efficiency change was progressed by $1.5 \%$. Given the value of technological change of 0.784 , it could be deduced that productivity gains are more likely to be as a result of improvements inefficiency in the period. The source of inefficiency is PECH $(+0.3 \%)$ which is success in adopting correct managerial decisions concerning input and output quantities but the value is less than SECH $(+1.2 \%)$. It means that it is highly likely that an improvement in 
scale efficiency has generated the resulting efficiency change. The DMUs are the countries used in this instance. All the DMUs are operating at productivity regress but Sierra Leone needs to be emulated because she has high technical efficiency change of $7.9 \%$ in the period and as well efficient as a result of PECH and SECH values of $1.7 \%$ and $6.2 \%$ respectively.

2001 - 2002: Despite the fact that average productivity growth was higher than the previous period, productivity is still regressed by $19.7 \%$. The technical efficiency change $(\mathrm{EFFCH})$ is constant while technological change was decreased by $19.7 \%$. The source of inefficiency which is pure technical efficiency change (PECH) was constant and SECH was as well constant in the period. Except Sierra Leone, all other DMUs are operating at a productivity regress. Technical change was increased by $15.3 \%$ in Sierra Leone likewise the productivity growth $(15.3 \%)$. The source of inefficiency and scale efficiency change were constant in the period.

2002 - 2003: The productivity at this period was progressed by $1 \%$ on the average. The technical efficiency change with the source of inefficiency $(\mathrm{PECH})$ and scale efficiency change were all constant in the period. The technological change $(\mathrm{TCHCH})$ was $1 \%$ progressed. It was observed in the period that Ghana, Liberia and Nigeria experienced productivity growth of $3.7 \%, 14.7 \%$ and $50 \%$ respectively in the period. And the same results were observed under technological change for each country (DMUs). The technical efficiency change, $\mathrm{PECH}$ and SECH were constant in the period.

2003 - 2004: There was a relative regress in the productivity by $1.3 \%$ while the EFFCH, PECH and SECH were constant on the average in the period. Liberia and Sierra Leone experienced productivity regress by $23 \%$ and $24 \%$ respectively in the period while The Gambia, Ghana and Nigeria experienced productivity progress by $5.6 \%$, $43.4 \%$ and $5.7 \%$ respectively in the period. The technological change (TECHCH) follows the same trend with the TFPCH in the period. Again, since the value of technical efficiency change (EFFCH) is greater than the value of $\mathrm{TECHCH}$, the productivity gains are more likely to be as a result of improvements in efficiency but none of the DMUs could emulate one another in order to be efficient.

2004 - 2005: On the average, the productivity was total regressed and technological change was zero. Other indices were constant in the period. Despite the average results, The Gambia, Liberia and Sierra Leone were experiencing productivity progress at $62.1 \%, 10.7 \%$ and $5.3 \%$ respectively in the period.

Table 4.1.1: Showing the statistics of entrepreneurship indicators in countries (2000 - 2014)

\begin{tabular}{|c|c|c|c|c|c|}
\hline Country & Statistics & EGR & ROE & DPI & EPS \\
\hline \multirow[t]{4}{*}{ The Gambia } & Mean & 469.3627 & 21.9667 & 21.1907 & 1.0000 \\
\hline & Minimum & 1.00 & 1.00 & 4.56 & 1.00 \\
\hline & Maximum & 637.10 & 31.80 & 31.70 & 1.00 \\
\hline & Std. Deviation & 149.93194 & 7.91262 & 8.77653 & .00000 \\
\hline \multirow[t]{4}{*}{ Ghana } & Mean & 969.6687 & 35.9667 & 25.0387 & 36845215.6667 \\
\hline & Minimum & 264.70 & 24.50 & 19.70 & 1.00 \\
\hline & Maximum & 1827.16 & 48.80 & 31.78 & 534537111.00 \\
\hline & Std. Deviation & 558.12115 & 7.73699 & 3.53031 & 137761562.69379 \\
\hline \multirow[t]{4}{*}{ Liberia } & Mean & 263.7827 & 19.6320 & 19.9520 & 1.0000 \\
\hline & Minimum & 133.15 & 7.90 & 7.50 & 1.00 \\
\hline & Maximum & 457.85 & 44.56 & 26.10 & 1.00 \\
\hline & Std. Deviation & 115.74192 & 10.97717 & 4.22356 & .00000 \\
\hline \multirow[t]{4}{*}{ Nigeria } & Mean & 1448.9300 & 34.3467 & 10.7967 & 1784141183.7333 \\
\hline & Minimum & 351.26 & 18.00 & 5.47 & 1.00 \\
\hline & Maximum & 3213.29 & 51.70 & 17.29 & 9959155144.00 \\
\hline & Std. Deviation & 1019.63107 & 8.99610 & 3.99780 & 2692867779.7287 \\
\hline \multirow[t]{4}{*}{ Sierra Leone } & Mean & 424.6833 & 292.4100 & 6.9704 & 388368.4480 \\
\hline & Minimum & 156.59 & 7.90 & 1.00 & 1.00 \\
\hline & Maximum & 783.11 & 4133.00 & 29.96 & 5636491.37 \\
\hline & Std. Deviation & 180.91796 & 1062.50697 & 7.03097 & 1452272.34233 \\
\hline \multirow[t]{4}{*}{ POOL } & Mean & 715.2855 & 80.8644 & 16.7897 & 364274953.9696 \\
\hline & Minimum & 1.00 & 1.00 & 1.00 & 1.00 \\
\hline & Maximum & 3213.29 & 4133.00 & 31.78 & 9959155144.00 \\
\hline & Std. Deviation & 679.35250 & 474.36549 & 8.90239 & 1373507964.0252 \\
\hline
\end{tabular}

2006 - 2007: About 4.7\% progress in productivity was observed in this period on the average and productivity gains were also observed among the DMUs except The Gambia, where Ghana, Liberia, Nigeria and Sierra Leone experienced a productivity gain of $4.3 \%, 29.8 \%, 4 \%$ and $27.6 \%$ respectively. Since TECHCH is greater than EFFCH, productivity gains are more likely as a result of technological progress.

2007 - 2008: The average productivity was highly regressed by $25 \%$ in the period. Except The Gambia and Ghana that experienced productivity gains of $4.7 \%$ and $6.7 \%$ respectively, all other DMUs experienced 
productivity retrogression in the period. The technical efficiency change, source of inefficiency and scale efficiency change were all constant in the period. It means that PECH and SECH are operating at the same rate. But one can still deduce that the productivity gain in this period is attributable to improvements in efficiency.

2008 - 2009: This period was better than the previous period where the average productivity gains were $42.4 \%$ and technological change was improved by $42.4 \%$ in the period. The TECHCH was greater than EFFCH, and this implies that productivity gains are mostly attributed to technological progress. Except Nigeria, about $9.2 \%$, $81.9 \%, 48.6 \%$ and $18.5 \%$ productivity gains were experienced in the period. The average value of TECHCH was greater than $\mathrm{EFFCH}$, meaning that the productivity gains are more likely as a result on the improvements on technological advancement.

2009 - 2010: Average productivity lost of $13.4 \%$ was observed in this period while the value of EFFCH was greater than $\mathrm{TECHCH}$ value, meaning that productivity lost is due to failure in efficiency in the period. Only Nigeria and Sierra Leone experienced productivity gains of $128.1 \%$ and $3.7 \%$ respectively and their productivity gains are mostly likely attributed to technological progress in the period.

2010 - 2011: On the average, there was productivity progress of $10.4 \%$ with technological improvements of $10.4 \%$ in the period. Since the value of TECHCH was greater than EFFCH value, the productivity gains are as a result of technological change. Only The Gambia and Nigeria experienced productivity gains of $111.7 \%$ and $47.5 \%$ respectively while their source of inefficiency and scale efficiency are constant in the period.

2011 - 2012: A very high average productivity gain was experienced in this period with $103.1 \%$ and same was observed for technological change. The value of TECHCH was $10.4 \%$ higher than EFFCH value, which implies that most of the productivity gains were attributable to technological improvements in the period. PECH and SECH values are 1, meaning that the pure technical efficiency and scale efficiency changes are constant returns to scale in the production function. Across the DMUs, except The Gambia that experienced productivity lost, Ghana, Liberia, Nigeria and Sierra Leone experienced a high productivity growth of 9.2\%, 68.7\%, 51.4\% and $47.4 \%$ respectively.

2012 - 2013: The average productivity loss was $4.1 \%$ in the period. The technological change failed by $4.1 \%$ in the period. Since EFFCH is greater than TECHCH, the productivity loss is most likely attributable to technological depression. All the DMUs experienced productivity loss except Nigeria that experienced a productivity progress of $9.9 \%$ in the period. The source of inefficiency and scale efficiency are constant in the period.

2013 - 2014: A very high average productivity gain (412.1\%) was observed in this period and likewise the technological improvements. The technical efficiency was constant, and PECH and SECH were also constant. The productivity loss could be attributable to technical efficiency failure since TECHCH value is greater than EFFCH value while the productivity gain was as a result of technological progress. According to the DMUs behaviour, it was observed that all the countries experienced productivity gain in the period. The source of inefficiency $(\mathrm{PECH})$ and scale efficiency change were constant in the period.

According to Table 4.1.2, the average TFPCH of 0.642 implies an average productivity regress of $35.8 \%$ annually with the study. The period of $2001-2002$ experienced productivity increase of $0.7 \%$ and further increased in $2002-2003$ by $20.7 \%$. The period 2003 - 2004 experienced productivity regress of $2.3 \%$ and later reduced to $0 \%$ in $2004-2005$. About $23.7 \%$ productivity progress was observed in $2005-2006$ but later decreased by $19 \%$ and $19.7 \%$ in the subsequent periods of $2006-2007$ and $2007-2008$ respectively. A very high productivity gain of $57.4 \%$ was further observed in 2008 - 2009 but regressed in $2009-2010$ by $55.8 \%$. Period $2010-2011$ experienced productivity progress of $23.8 \%$ and further progressed by $92.7 \%$ in $2011-2012$. A productivity loss of $107.2 \%$ was experienced in $2002-2013$ period but 2013 - 2014 experienced very high productivity progress of $416.2 \%$ in the period. The technical efficiency change (EFFCH) progress by $0.1 \%$ annually while the technological change (TECHCH) regressed by $35.9 \%$ annually. From the Table, it can be deduced that productivity gains are more likely to be as a result of improvements in efficiency in the years under the study. The source of inefficiency $(\mathrm{PECH})$ was constant while the scale efficiency $(+0.1 \%)$ as the DMUs are trying to get closer to the optimal size to realize the economies of scale although it is very weak and small. Therefore, since PECH is less than SECH value, it is highly likely that an improvement in scale efficiency has generated the resulting efficiency change. It was also observed that only period 2000 - 2001 slightly experienced to be efficient given the value of PECH (0.3\%) and SECH (1.2\%), and this implies that they are embracing technology and as well improving their managerial allocative efficiency, and therefore optimizing their DMUs economies of scale. 
Table 4.1.2: Showing average efficiencies from $2000-2014$

\begin{tabular}{|l|l|l|l|l|l|}
\hline Year & \multicolumn{1}{|c|}{ EFFCH } & \multicolumn{1}{|c|}{ TECHCH } & \multicolumn{1}{c|}{ PECH } & \multicolumn{1}{c|}{ SECH } & \multicolumn{1}{c|}{ TFPCH } \\
\hline $2000-2001$ & 1.015 & 0.784 & 1.003 & 1.012 & 0.796 \\
\hline $2001-2002$ & 1 & 0.803 & 1 & 1 & 0.803 \\
\hline $2002-2003$ & 1 & 1.01 & 1 & 1 & 1.01 \\
\hline $2003-2004$ & 1 & 0.987 & 1 & 1 & 0.987 \\
\hline $2004-2005$ & 1 & 0 & 1 & 1 & 0 \\
\hline $2005-2006$ & 1 & 1.237 & 1 & 1 & 1.237 \\
\hline $2006-2007$ & 1 & 1.047 & 1 & 1 & 1.047 \\
\hline $2007-2008$ & 1 & 0.85 & 1 & 1 & 0.85 \\
\hline $2008-2009$ & 1 & 1.424 & 1 & 1 & 1.424 \\
\hline $2009-2010$ & 1 & 0.866 & 1 & 1 & 0.866 \\
\hline $2010-2011$ & 1 & 1.104 & 1 & 1 & 1.104 \\
\hline $2011-2012$ & 1 & 2.031 & 1 & 1 & 2.031 \\
\hline $2012-2013$ & 1 & 0.959 & 1 & 1 & 0.959 \\
\hline $2013-2014$ & 1 & 5.121 & 1 & 1 & $\mathbf{1}$ \\
\hline Mean & $\mathbf{1 . 0 0 1}$ & $\mathbf{0 . 6 4 1}$ & $\mathbf{1}$ & $\mathbf{1 . 0 0 1}$ & $\mathbf{0 . 6 4 2}$ \\
\hline
\end{tabular}

The productivity changes of individual DMUs were presented in Table 4.3 and this attempts to find out the best performers and what can be learnt from one another to improve efficiency over time. It was observed that The Gambia, Ghana, Liberia and Sierra Leone have productivity progress of $8 \%, 19 \%, 8.3 \%$ and $25.2 \%$ respectively annually. Only Nigeria has productivity regress of $93.8 \%$ annually in the study. The value of EFFCH suggests that technical efficiency change progress by $0.1 \%$ annually while TECHCH regress by $35.9 \%$ annually. Since the PECH value is less than SECH value, one can conclude that it is highly likely that an improvement in scale efficiency has generated the resulting efficiency changes.

All the DMUs are constant under PECH and SECH except in Sierra Leone where the source of inefficiency is $\mathrm{PECH}(0.1 \%)$ which implies a slight success in adopting correct managerial decisions concerning inputs and output quantities while the scale inefficiency $(0.4 \%)$ indicated that Sierra Leone is getting closer to the optimal size to realize the economies of scale. Therefore, the other DMUs can learn something from Sierra Leone being the best of the DMUs' class performer to enhance their productivity.

Table 4.1.3: Showing productivity changes of individual DMUs

\begin{tabular}{|l|l|l|l|l|l|}
\hline \multicolumn{1}{|c|}{ COUNTRY } & \multicolumn{1}{c|}{ EFFCH } & TECHCH & \multicolumn{1}{c|}{ PECH } & SECH & TFPCH \\
\hline The Gambia & 1 & 1.08 & 1 & 1 & 1.08 \\
\hline Ghana & 1 & 1.19 & 1 & 1 & 1.19 \\
\hline Liberia & 1 & 1.083 & 1 & 1 & 1.083 \\
\hline Nigeria & 1 & 0.062 & 1 & 1 & 0.062 \\
\hline Sierra Leone & 1.005 & 1.245 & 1.001 & 1.004 & 1.252 \\
\hline Mean & $\mathbf{1 . 0 0 1}$ & $\mathbf{0 . 6 4 1}$ & $\mathbf{1}$ & $\mathbf{1 . 0 0 1}$ & $\mathbf{0 . 6 4 2}$ \\
\hline
\end{tabular}

\subsection{The Efficiencies in Francophone West African Countries}

In 2000 - 2001, there was high productivity decrease of 34.7\%. All the DMUs experienced decrease in productivity growth. The EFFCH suggests a small regress of $0.5 \%$ while $\mathrm{TECHCH}$ experiences high technological change decrease of $34.3 \%$. The source of inefficiency is PECH and it indicates stagnation in adopting correct managerial decisions concerning inputs and outputs quantities. The scale inefficiency (SECH) of $-0.5 \%$ indicated that the countries failed to get closer to the optimal size to realize the economies of scale.

2001- 2002: The average TFPCH value of 0.013 implies an average productivity regress of $1.3 \%$ in the year. It was observed that Ivory Coast, Mali and Burkina Faso experienced productivity progress by $11.4 \%, 3.4 \%$ and $50.8 \%$ respectively in the year. The value of technical efficiency change $(\mathrm{EFFCH})$ implies $0.5 \%$ improvement in the productivity. Mali was the only country that has improvement on technological efficiency change in the period given the value of $2.5 \%$ while TECHCH of $1.7 \%$ indicated an improvement on the average. Ivory Coast, Mali and Burkina Faso experienced technical change improvement of $11.4 \%, 0.8 \%$ and $50.8 \%$ respectively. The average source of inefficiency $(\mathrm{PECH})$ was stagnant and likewise among the countries. The scale inefficiency $(0.5 \%)$ is progressing at a small rate to get closer to the optimal size realize the economies of scales. Other DMUs should emulate Mali in this period.

2002 - 2003: The mean TFPCH indicates a positive productivity growth by $33.7 \%$ in the period. Except Burkina Faso and Ivory Coast, all of them experience productivity progress. EFCH was stagnant in the period. The Technological Change (TECHCH) was progressed by $33.7 \%$ and it cut across the whole countries except Ivory Coast and Burkina Faso. The source of inefficiency is PTECH and SECH were stagnant in the period. 
2003-2004: The average TFPCH (13.9\%) implies a productivity regress while all the countries experienced productivity regress except Ivory Coast which experienced a productivity progress of $33.7 \%$. EFFCH was stagnant while TECHCH showed a regress in technical efficiency change by $34.3 \%$. The PECH was stagnant while SECH $(-0.5 \%)$ indicated a failure to get closer to the optimal size to realize the economies of scale.

Table 4.2.1: Showing the statistics of entrepreneurship indicators in countries $(2000-2014)$

\begin{tabular}{|c|c|c|c|c|c|}
\hline Country & Statistics & EGR & ROE & DPI & EPS \\
\hline \multirow{4}{*}{$\begin{array}{l}\text { Ivory } \\
\text { Coast }\end{array}$} & Mean & 1070.2247 & 46.9933 & 474541578.7497 & 4872043.9503 \\
\hline & Minimum & 648.80 & 40.70 & 5.62 & -4906444.30 \\
\hline & Maximum & 1545.90 & 53.80 & 7118123578.00 & 30443161.41 \\
\hline & Std. Deviation & 277.89997 & 4.15958 & 1837891603.01854 & 8766261.21797 \\
\hline \multirow[t]{4}{*}{ Mali } & Mean & 496.8827 & 33.9067 & 10.9996 & 627634.3186 \\
\hline & Minimum & 240.37 & 22.80 & 8.53 & -6405618.15 \\
\hline & Maximum & 704.50 & 52.40 & 12.81 & 13539534.00 \\
\hline & Std. Deviation & 163.04726 & 11.68653 & 1.32188 & 4990541.54216 \\
\hline \multirow[t]{4}{*}{ Senegal } & Mean & 846.9560 & 26.4467 & 37.5153 & -5548034.8418 \\
\hline & Minimum & 474.57 & 24.30 & 17.18 & -92607220.40 \\
\hline & Maximum & 1094.57 & 28.70 & 225.50 & 23348549.39 \\
\hline & Std. Deviation & 230.47306 & 1.45743 & 52.16706 & 26438604.73545 \\
\hline \multirow[t]{4}{*}{ Benin } & Mean & 12441.9013 & 22.4067 & 15.0814 & 1595574.1241 \\
\hline & Minimum & 369.70 & 18.50 & 11.24 & -2905629.60 \\
\hline & Maximum & 90346.00 & 36.10 & 20.12 & 8981624.59 \\
\hline & Std. Deviation & 31208.98406 & 4.53675 & 2.54616 & 3023600.54077 \\
\hline \multirow{4}{*}{$\begin{array}{l}\text { Burkina } \\
\text { Faso }\end{array}$} & Mean & 479.1400 & 15.1333 & 11.8783 & -20784300.7525 \\
\hline & Minimum & 226.80 & 8.70 & 8.98 & -193630055.80 \\
\hline & Maximum & 713.06 & 28.90 & 17.61 & 65580540.82 \\
\hline & Std. Deviation & 172.09628 & 7.49206 & 3.20574 & 71158571.14744 \\
\hline \multirow[t]{4}{*}{ POOL } & Mean & 3067.0209 & 28.9773 & 94908330.8449 & -3847416.6402 \\
\hline & Minimum & 226.80 & 8.70 & 5.62 & -193630055.80 \\
\hline & Maximum & 90346.00 & 53.80 & 7118123578.00 & 65580540.82 \\
\hline & Std. Deviation & 14374.44539 & 12.79233 & $\begin{array}{l}821930110.8489 \\
9\end{array}$ & 34574555.06523 \\
\hline
\end{tabular}

2004-2005: On average, a productivity regress was experienced by $20.7 \%$. The EFCH was stagnant while TECHCH showed a productivity decrease of $20.7 \%$. The sources of inefficiencies by PECH and SECH were stagnant in the period.

2005-2006: The DMUs experienced very high productivity growth with an average of $108.7 \%$ progress. The EFFCH and their inefficiency sources (PECH and SECH) were stagnant. The technical change experienced $108.7 \%$ productivity increase.

2006-2007: The average TFPCH showed a productivity regress of $9.3 \%$ and the same was experienced by technical change (TECHCH). Across the DMUs, only Ivory Coast and Burkina Faso experienced productivity improvement by $6.4 \%$ and $33.2 \%$ respectively.

2007-2008: All the countries experienced a productivity regress of $46.0 \%$ on the average and the result was observed on the technical change. EFFCH, PECH, and SECH were stagnant in the period.

2009-2010: Despite an increase in productivity growth in Ivory Coast, Mali and Senegal by $6.4 \%, 42.5 \%$ and $1.8 \%$ respectively, the average TFPCH still indicated a productivity regress $28.1 \%$. The average EFFCH indicated productivity retrogressive with a technological change of $27.9 \%$ regress.

2008-2009: Despite a great or high increase (167.6\%) on productivity growth, EFFCH, SECH and PECH were stagnant in the period. All the DMUs had very high productivity growth.

2010-2011: There was great retrogression in the productivity in this period on the average but Benin experienced a productivity progress of $21.6 \%$.

2011-2012: There was high productivity decrease in this period while the technological change increase by $2.5 \%$. The PECH was $2.5 \%$ efficient on the average.

2012-2013: Despite a sharp decrease on average productivity, Mali, Benin and Burkina Faso experienced a high increase in productivity by $23 \%, 787.6 \%$ and $29.4 \%$ respectively. The EFFCH decreased in productivity by $0.2 \%$ while the scale inefficiency was $-0.2 \%$.

2013-2014: All the DMUs experienced productivity progress except Ivory Coast and technical efficiency change was regressed by $3.6 \%$ with inefficiency source of $-3.6 \%$.

From Table 4.2.2, the average TFPCH of 0.674 implies a productivity regress of $32.6 \%$ over the years. 2000 2001 experienced a high productivity decrease of 34.7\%. 2001-2002 experienced productivity increase by $33.4 \%$; 
2002-2003 experienced productivity increase by $35.0 \%$. It was decreased sharply by $47.6 \%$ in $2003-2004$ periods. 2004-2005 experienced further productivity decrease $6.8 \%$, but a significant increase in productivity was experienced in $2005-2006$ by $129.4 \%$ while a sharp and significant productivity decrease was experienced in 20062007 by $118 \%$.

2007-2008 experienced productivity decrease of $36.7 \%$ but $2008-2009$ experienced super increase of $213.6 \%$ but decrease by $195.7 \%$ in 2009-2010. No productivity was experienced from 2010-2011 to 2013-2014 periods. There is technical efficiency change regress by $0.3 \%$ annually while technical change decreases by $32.4 \%$.

The sources of inefficiency PECH was stagnancy over the years while scale efficiency was inefficient by $0.3 \%$.

Table 4.2.2: Showing average efficiencies from $2000-2014$

\begin{tabular}{|c|c|c|c|c|c|}
\hline Year & EFFCH & TECHCH & $\mathrm{PECH}$ & SECH & TFPCH \\
\hline $2000-2001$ & 0.995 & 0.657 & 1 & 0.995 & 0.653 \\
\hline $2001-2002$ & 1.005 & 0.983 & 1 & 1.005 & 0.987 \\
\hline $2002-2003$ & 1 & 1.337 & 1 & 1 & 1.337 \\
\hline $2003-2004$ & 1 & 0.861 & 1 & 1 & 0.861 \\
\hline $2004-2005$ & 1 & 0.793 & 1 & 1 & 0.793 \\
\hline $2005-2006$ & 1 & 2.087 & 1 & 1 & 2.087 \\
\hline $2006-2007$ & 1 & 0.907 & 1 & 1 & 0.907 \\
\hline $2007-2008$ & 1 & 0.54 & 1 & 1 & 0.54 \\
\hline $2008-2009$ & 1 & 2.676 & 1 & 1 & 2.676 \\
\hline $2009-2010$ & 0.997 & 0.721 & 1 & 0.997 & 0.719 \\
\hline $2010-2011$ & 0.978 & 0 & 1 & 0.978 & 0 \\
\hline $2011-2012$ & 1.025 & 1 & 1.025 & - & - \\
\hline $2012-2013$ & 0.998 & 0 & 1 & 0.998 & 0 \\
\hline $2013-2014$ & 0.964 & 1 & 0.964 & - & - \\
\hline Mean & 0.997 & 0.676 & 1.000 & 0.997 & 0.674 \\
\hline
\end{tabular}

From Table 5, Ivory Coast experienced a high productivity decrease/regress of $92.8 \%$; Mali experienced a small productivity regress of $5.2 \%$ and Burkina Faso experienced a small productivity regress of $3.8 \%$ annually. Senegal and Benin experienced productivity progress of $60.8 \%$ and $31.6 \%$ respectively annually. The average TFPCH of 0.674 implies an average productivity regress of $32.6 \%$ annually with the study period.

The technical efficiency change $(\mathrm{EFFCH})$ was regressed by $0.3 \%$ annually while technological change (TECHCH) was also regressed by $32.4 \%$ annually. The value of PECH was equal to 1 in all the DMUs which indicate stagnation in the efficiency while SECH was equal to 1 in all the countries except Mali which experienced inefficiency of $1.3 \%$.

This showed that the inefficiency/short-fall is coming from technical inefficiency in terms of managerial skills deficit required to optimally increase the return on outputs from the given set of inputs.

Table 4.2.3: Showing productivity changes of individual DMUs

\begin{tabular}{|l|l|l|l|l|l|}
\hline Country & EFFCH & TECHCH & PECH & SECH & TFPCH \\
\hline Ivory Coast & 1 & 0.072 & 1 & 1 & 0.072 \\
\hline Mali & 0.987 & 0.961 & 1 & 0.987 & 0.948 \\
\hline Senegal & 1 & 1.608 & 1 & 1 & 1.608 \\
\hline Benin & 1 & 1.316 & 1 & 1 & 1.316 \\
\hline Burkina Faso & 1 & 0.962 & 1 & 1 & 0.962 \\
\hline Mean & $\mathbf{0 . 9 9 7}$ & $\mathbf{0 . 6 7 6}$ & $\mathbf{1}$ & $\mathbf{0 . 9 9 7}$ & $\mathbf{0 . 6 7 4}$ \\
\hline
\end{tabular}

\section{Conclusion}

In this paper, the efficiencies of selected entrepreneurship indicators at macro level in both Anglophone and Francophone West African countries were examined. The study found that cumulatively, the Anglo West African countries were entrepreneurship enhancing while the francophone countries are entrepreneurship inhibiting. Of interest to us, was the question of whether the dependence of central bank and the emerging stock exchange market has either made or mar entrepreneurship in the region. However, despite the fact that the emerging capital market operating in the francophone divide remains relatively small and illiquid, the performance of the stock market variable was slight higher than in the Anglophone countries.

From the efficiency analysis on the Anglophone divide, the Pure Technical Efficiency Change (PECH) is less than the Scale Efficiency Change (SECH) value, it is highly likely that an improvement in scale efficiency has generated the resulting efficiency change. It was also observed that only period $2000-2001$ slightly experienced to be efficient given the value of PECH (0.3\%) and SECH (1.2\%), and this implies that the countries in the divide are embracing technology and as well improving their managerial allocative efficiency, and therefore optimizing 
their DMUs (countries) economies of scale. It is highly likely that an improvement in scale efficiency has generated the resulting efficiency changes. All the DMUs (countries) are constant under PECH and SECH except in Sierra Leone where the source of inefficiency is PECH $(0.1 \%)$ which implies a slight success in adopting correct managerial decisions concerning inputs and output quantities while the scale inefficiency $(0.4 \%)$ indicated that Sierra Leone is getting closer to the optimal size to realize the economies of scale. Therefore, the other DMUs can learn something from Sierra Leone being the best of the DMUs' class performer to enhance their productivity. While the efficiency analysis on the Francophone divide revealed that there was a sharp decrease on average productivity, but Mali, Benin and Burkina Faso experienced a high increase in productivity. All the DMUs (countries) experienced productivity progress except Ivory Coast and technical efficiency change was also regressed. This could be as a result of scoring low in the constant election variable during the period under review. However, the general inefficiency/short-fall is coming from technical inefficiency in terms of managerial skills deficit required to optimally increase the return on outputs from the given set of inputs. It was however recommended that public policies should be more focused on engendering technical efficiencies of entrepreneurship pursuit in the Region.

\section{References}

Abou-Strait, F. (2005). Are Exports The Engine Of Economic Growth? An Application of Cointegration and Causality Analysis for Egypt, 1977-2003. African Development Bank, Economic Research Working Paper.

Acemoglu D., Johnson S, \& Robinson J. A. (2001). The Colonial Origins of Comparative Development: An Empirical Investigation. The American Economic Review, Vol. 91, No. 5 (Dec., 2001), pp. 1369-1401 Published by: American Economic Association

Acs, Z. J. (2008). Entrepreneurship, Growth and Public Policy Prelude to a Knowledge Spillover Theory of Entrepreneurship. Cheltenham: Edward Elgar.

Adenikinju, A. F., (2005). African Imperatives in the New World Trade Order: country Case Study of the Manufacturing Sector in Nigeria, in Ogunkola O, E. and Bankole A. (eds) Nigeria's Imperatives in the New World Trade Order, Africa Economic Research Consortium (Nairobi, Kenya) and the Trade Policy Research and Training Programme (Ibadan, Nigeria).

Adesoji, A.A and Sotubo, O.D. (2013) Non-Oil Exports in the Economic Growth of Nigeria: A Study of Agricultural and Mineral Resources. Journal of Educational and Social Research Vol. 3 (2) May 2013

Adjasi, C.K.D \& Biekpe, N.B. (2006) Stock Market Development and Economic Growth: The Case of Selected African Countries. African Development Review, Volume 18, Issue 1, pages 144-161, April/Avril 2006

Agboli, M and Ukaegbu, C. C. (2006). Business environment and entrepreneurial activity in Nigeria: implications for industrial development. Journal of Modern African Studies, 44, 1: 1-30

Ahmad, N. and Hoffman, A. (2007). A Framework for Addressing and Measuring Entrepreneurship. OECD, Entrepeneurship Indicators Steering Group, Paris, 20 November 2007.

Akinyosoye, V. O., Akande, S. O., Akpokodje, G. and Mbanefoh N. B. (1998) Trade and Exchange Rate Liberalization and Competitiveness of Nigeria's Tradable Commodities, Monograph published by the Nigerian Institute of Social and Economic Research.

Allen R.C. (2001). The Great Divergence in European Wages and Prices from the Middle Ages to the First World War. Explorations in Economic History 38, 411-447 (2001)

Ascharer, D. A. (1989). Does public capital crowd out private capital? Journal of Monetary Economics, 24: 171 $-188$.

Atkinson, A. and Correa, D. (2007). The 2007 state new economy index. Benchmarking economic transformation in States, Information technology and Innovation foundation, Washington

Audretsch, D.B. and Thurik, A.R. (2001). What's new about the new economy? Sources of growth in the managed and entrepreneurial economies. Industrial and Corporate Change, 10(1) 267-315.

Bagehot, W. (1873), Lombard Street: A Description of the Money Market . London: John Murray, 1873. Reprinted (with introduction by Hartley Withers). London: William Clowes and Sons, 1924.

Baumol, W. J. (1990). Entrepreneurship: Productive, unproductive, and destructive. Journal of Political Economy, 98(5), 893-921.

Beck, T.and Levine, R. (2004). "Stock markets, banks and growth: Panel evidence". Journal of Banking and Finance, 423-442.

Berger, A. \& Humphrey, D., 1997. Efficiency of financial institutions: international survey and directions for further research. European Journal of Operational Research, Volume 98, pp. 175-2012.

Bergmann, H.; Mueller, S.; Schrettle, T. (2013): The Use of Global Entrepreneurship Monitor Data in Academic Research: A Critical Inventory and Future Potentials. In: Int.J. Entrepreneurial Venturing.

Blanchflower, D., Oswald, A., \& Stutzer, A. (2001), “Latent entrepreneurship across nations?" European Economic Review, 45,680-691.

Boyd, J.H. and Champ, B. 2003. Inflation and financial market performance: What have we learnt in the last ten 
years? Federal Reserve Bank of Cleveland Working Paper 03-17: Cleveland: Federal Reserve Bank of Cleveland.

Charnes, A., Cooper, W.W., and Rhodes, E. (1978), "Measuring the efficiency of decision making units", European Journal of Operational Research 2, 429-444.

Child, J. Lu, Y. and Hung, S. 2007. 'Terence Tsai Institutional Entrepreneurship in building an Environmental Protection System for the People's Republic of China'. Organization

Clausen, T.H. (2006), "Who identifies and Exploits entrepreneurial opportunities", Retrieved from www.ccsr.ac.uk.

Collier, P. (1995), 'The marginalization of Africa'. International Labour Review, 134 (4-5), 541 - 557.

Davidson, P., \& Honing, B. (2003), The role of social and human capital among nascent entrepreneurs, Journal of Business Venturing, 20,121

Dehn, J. (2000), 'Private investment in developing countries: The effect of commodity shocks and uncertainty. Oxford: Center for the study of African Economics, University of Oxford.

Dennis, W.J. Jr. (2005). Entrepreneurship, small business and public policy levers. Journal of Small Business Management, 29(2), 149-162.

Edame, G.E and W.M. Fonta (2014). The Impact of Government Expenditure on Infrastructure in Nigeria: A Cointegration \& Error Correction Specification. International Journal of African and Asian Studies - Vol.3,

Enisan, A. A., and A. O. Olufisayo (2009) 'Stock market development and economic growth: Evidence from seven sub-Saharan African countries', Journal of Economics and Business, Vol. 61 (2), pp. 162-171.

Evans, David \& Boyan, Jovanovic (1989). An Estimated Model of Entrepreneurial Choice under Liquidity Constraints. Journal of Political Economy: 808-827

Greenaway, D. \& Morrissey, O. (1992), "Structural adjustment and liberalization in developing countries: What lesson have we learned? Kyklos, 46, $241-261$.

Grossman, G.M. and E. Helpman (1991). Innovation and Growth in the Global Economy, Cambridge,

Gunning, J. (1994). The Manufacturing Sector in Zimbabwe: Survey Evidence on Growth, Adjustment and Vulnerability, Department of Economics, Free University, Amsterdam.

Gurley, J. G. and Shaw, E. S. (1955). Financial Aspects of Economic Development." American Economic Review, September 1955, 45(4), pp. 515-38.

Gurley, J. G. and Shaw, E. S. (1960). Money in a Theory of Finance. Washington, DC: Brookings Institution, 1960.

Gurley, J. G. and Shaw, E. S. (1967) Financial Structure and Economic Development." Economic Development and Cultural Change, April 1967, 15(3), pp. 257-68.

Harper, D.A. (2003) Entrepreneurship and the Market Process: An Enquiry into the Growth of Knowledge, London and New York: Routledge

Hayek, F.A. (1976), "Denationalization of Money", Hobart Special Paper, No. 70, Institute of International Affairs, London.

Hindle, Kevin 2009. The relationship between innovation and entrepreneurship: easy definition, hard policy. Paper delivered to the refereed stream of the 6th AGSE International Entrepreneurship Research Exchange. 3-6 February. Adelaide, South Australia, Australia

Keynes, J. M. (1930). A Treatise on Money, MacMillan, London.

Keynes, J. M. (1936). The General Theory of Employment, Interest and Money, MacMillan, London.

Khosravi, A and Karimi, M.S. (2010). To Investigate the Relationship between Monetary, Fiscal Policy and Economic Growth in Iran: Autoregressive Distribution Lag Approach to Cointergration, American Journal of Applied Sciences, 7, Number 3, 420-424

Knoop, Todd A. (2008). Modern Financial Macroeconomics: Panics, Crashes and Crises. Plublished by WileyBlackwell

Murdock K.A. (2009). Public policy for Entrepreneurship and Innovation. Trade-offs and impacts in Managed and Entrepreneurial economies. Unpublished $\mathrm{PhD}$ thesis, University of Barcelonia.

Naudé, W. (2007) 'Peace, Prosperity, and Pro-Growth Entrepreneurship', Helsinki: United Nations University.

Ncube, Mthuli (2015), Economic Growth, Entrepreneurship and the Business Environment in Africa. Working Paper Number 30. University of Johannesburg

North, Douglas C. (1981). Structure and Change in Economic History, W.W. Norton

Organisation for Economic Co-operation and Development (OECD) 2011. Entrepreneurship at a Glance 2011. Paris: Organization for Economic Co-operation and Development Publishing.

Paradi, J. C. \& Zhu, H., (2013). A survey on bank branch efficiency and performance researc with Data Envelopment Analysis. Omega, Volume 41, pp. 61-79).

Prakash T. and Cabezon E (2008). Public Financial Management and Fiscal Outcomes in Sub-Saharan African Heavily-Indebted Poor Countries. WP/08/217. International Monetary Fund, September, 2008.

Rashid, A. (2005), "Public - private investment linkage. A multivariate co-integration analysis. 21st Annual 
General Meeting and Conference, Pakistan Institute of Development Economics, Islamabad, December 19 21.

Saisana, M., \& Munda, G. (2008). Knowledge Economy: Measures and Indicators, Working Paper EUR 234BB EN 2008, European Commission Joint Research Centre, Italy

Sanchez-Robles B (1998). Infrastructural investment and growth: Some empirical evidence. Contemporary Economic Policy, 16: 98-108.

Schumpeter, J. (1934). The theory of Economic Development. Cambridge, USA: Harvard University Press

Serven, L. \& Salimano, A. (1992), "Private investment and macroeconomic adjustment: A survey, World Bank Research Observer, 7(1), $95-114$.

Storey, D.J. (2008). Entrepreneurship and SME Policy. Lyon: World Entrepreneurship Forum.

Tawiri, N. (2010), Domestic Investment as a drive of economic growth in Libya. International Conference on Applied Economics - ICOAE, 759 - 767..

Thanassoullis, E., Boussofiane, A. \& Dyson, R., 1996. A comparison of data envelopment analysis and ratio analysis as tools for performance assessment. Omega, Volume 24, pp. 229-244.

Udjo EO, Simelane S, Booysen D (2000). Socio-economic indicators of development progress within the OECD framework in South Africa. Paper presented at the Millennium Conference of Commonwealth Statisticians, Botswana,1-5 May 2000 www.statssa.gov.za

van Praag, C.M and Versloot, O.H (2007). What is the value of entrepreneurship? A review of recent research. Small Business Economics, 29(4), 351-382

Wennekers, S. and Thurik, R. (1999). Linking entrepreneurship and economic growth. Small Business Economics, $13(1), 27-55$ 